18. Tessera

\title{
This Land Is Mimed Land
}

Shelley Niro

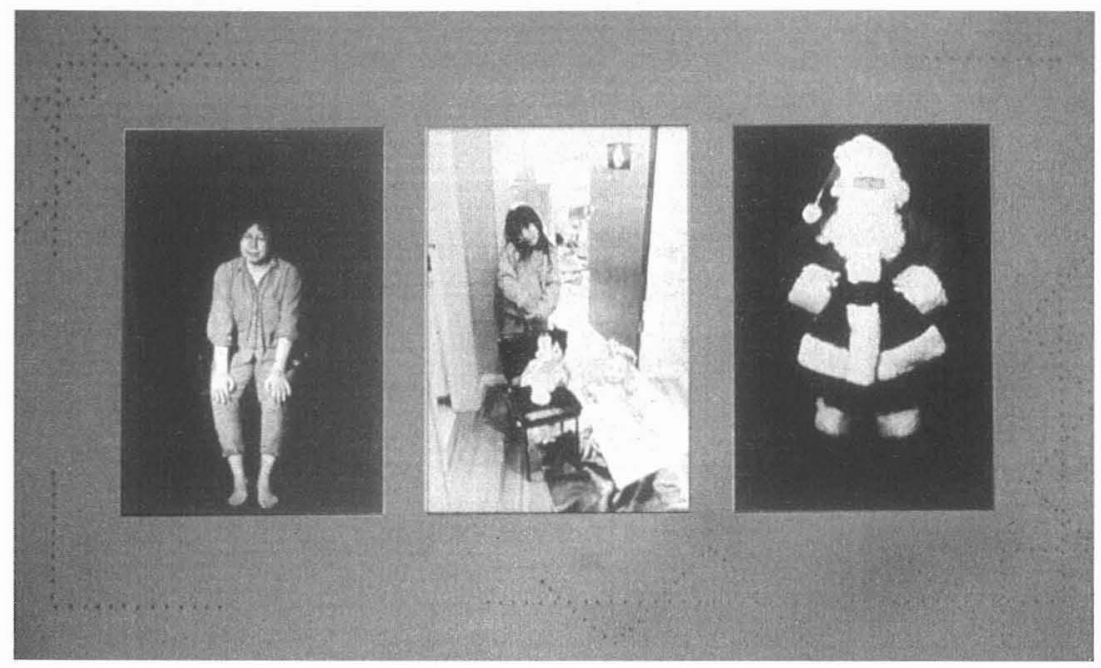

Santa Is a Dene / Le Père Noël est Dene 
This Land Is Mimed Land . 19

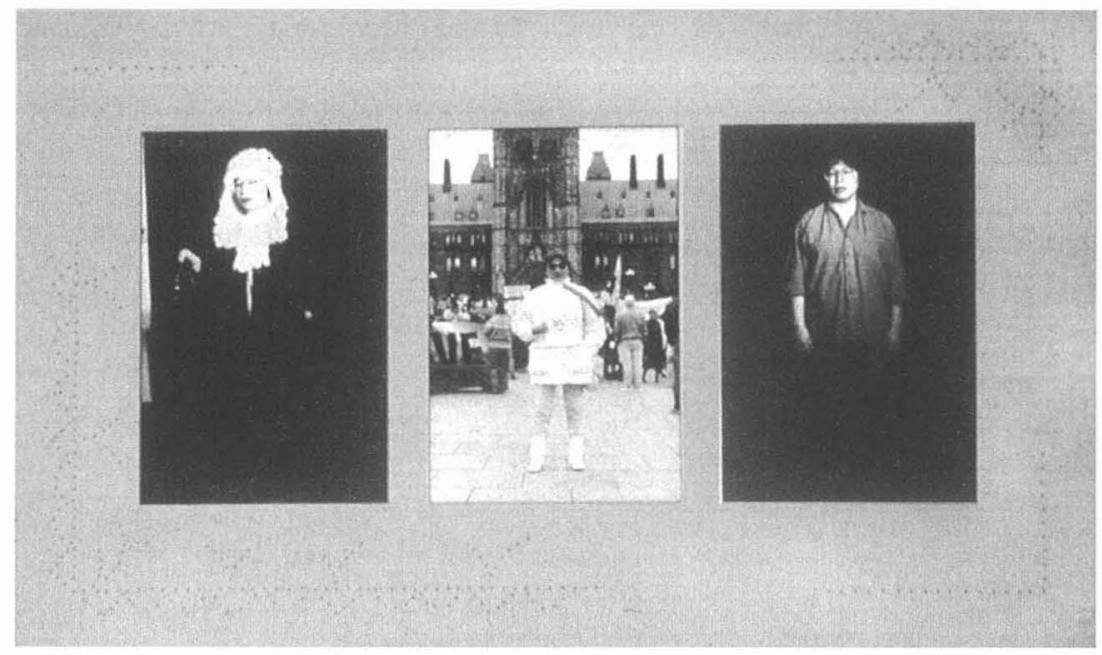

Judge Me Not / Ne me jugez pas 